\title{
Low-intensity pulsed ultrasound improves behavioral functions and alleviates neuroinflammation in a rat model of Parkinson's disease
}

Research

Keywords:

Posted Date: November 2nd, 2020

DOl: https://doi.org/10.21203/rs.3.rs-92250/v2

License: (1) This work is licensed under a Creative Commons Attribution 4.0 International License. Read Full License 


\section{Abstract}

The authors have requested that this preprint be withdrawn due to author disagreement.

\section{Full Text}

The authors have withdrawn this preprint from Research Square. 